\title{
The Relationship between ES-QUAL Model and Online Purchase Intention in the Context of Rising Global Marketplace of E-Commerce
}

\author{
Sana Baqai ${ }^{1}$, Jawaid Ahmed Qureshi2 ${ }^{2}$, Ejindu Iwelu MacDonald Morah ${ }^{3}$ \\ ${ }^{1,2}$ Shaheed Zulfikar Ali Bhutto Institute of Science and Technology (SZABIST), Pakistan \\ ${ }^{3}$ University of Westminster, United Kingdom \\ E-mail: ${ }^{1}$ rjsanarehman@hotmail.co.uk, ${ }^{2}$ jawaid.qureshi@szabist.edu.pk, ${ }^{3}$ e.morah@westminster.ac.uk
}

${ }^{*}$ Corresponding Author

\section{JEL Classification:}

M31

L81

Received: 12 May 2021

Revised: 08 August 2021

Accepted: 30 August 2021

\begin{abstract}
The global ecommerce has fostered the global trade many folds. The electronic service quality (ES-QUAL) of the e-commerce service providers plays a central role. The primary purpose of this paper is to investigate the effect of the ES-QUAL model's four dimensions (efficiency, fulfillment, privacy, and system availability) on purchase intention and examine ES-QUAL's relationship with electronic word-of-mouth (EWOM), brand image, and purchase intention. This research uses Structural Equation Modeling (SEM) for empirical analysis. Results show ES-QUAL model positively and significantly impacts purchase intention, and the effect of the ES-QUAL model relatively increases when mediated by electronic word of mouth (EWOM) and brand image. This research provides insights to E-marketers, entrepreneurs, and e-commerce players to improve online consumers' purchase intention, sales, and services. Practitioners can gain customers' attention by enhancing the quality of their websites and by assuring efficiency, privacy, system availability, and fulfilling their promise about delivering products. They also need to consider EWOM and brand image, as both positively impact online purchase intention, which can lead to the overall sustainable development of an organization.
\end{abstract}

Keywords:

ES-QUAL model, electronic word of mouth (EWOM), brand image, purchase intention, digital marketing, e-commerce

\section{How to Cite:}

Baqai, S., Qureshi, J. A., \& Morah, E. I. M. (2021). The Relationship Between ES-QUAL Model and Online Purchase Intention in the Context of Rising Global Marketplace of E-Commerce. Etikonomi, 20(2), 319 - 338. https://doi. org/10.15408/etk.v20i2.20677. 


\section{Introduction}

Global e-commerce has increased global trade many folds. Multinational and global companies, startups, and small and medium enterprises (SMEs) sell their products online. E-retailers observe buying and selling trends in individual target markets and offer customized products to match the local customers' needs and demands. It translated into the emergence of hyper-localization, which became a new strategy in global e-commerce (Singh \& Keating, 2018). With the advent and advancement of globalization and digitization or so-called digital-globalization, the global supply chain has been reshaped due to technological breakthroughs (Baqai \& Qureshi, 2020; Herold et al., 2021). In the wake of the sudden assault of the pandemic COVID-19, the global e-commerce industry observed an unexpected boost to US\$26.7 trillion in 2019, as per the available statistics. However, a few sectors like ride-hailing and online travel services recorded losses. The top three countries in the global e-commerce marketplace include China, the USA, and the UK. While surprisingly, the Republic of Korea is at number four. In the arena of business to consumers (B2C) e-commerce companies, two China-based global companies won two slots in the top-three companies, including Alibaba, followed by Amazon USA and JD.com from China (United Nations Conference on Trade and Development, 2021).

The spectrum of online shopping is one of the widely growing business developments, altering the way customers shop (Nagra \& Gopals, 2013). Online shopping possesses an apex position to increase customers' satisfaction and loyalty. In developed countries, online shopping is now considered the most convenient medium of buying. Since in e-business, everything is just one click away where customers shop ubiquitously or 24/7. This trend is getting widely popular in Asia, specifically in the least developed countries (Bashir et al., 2015), because it is considered the most convenient way of shopping. It provides a wide variety and choices with one click, and customers can easily match prices in their range and compare the different products in terms of quality and prices to make decisions. In today's fast and busy life, online shopping provides contentment and peace to those customers who desire to get a more convenient way to shop without wasting time (Yu \& Wu, 2007). Despite its wide popularity and convenience, online shopping in Pakistan is not growing on the ideal model. The majority of the customers do not rely on the services or products being sold online as they display something else and deliver something else, and customers end up disappointed. Researchers claim that looking at the shoppers can provide vital guidelines for its growth (Bashir et al., 2015).

For fostering global trade, ecommerce has played the foremost essential role. Ecommerce requires interaction between the global buyers and sellers through the Internet, i.e., via websites, social media, emails, and other digital means including the digital marketing tools. In this nexus, e-service quality plays a pivotal role. ES-QUAL model's four dimensions (efficiency, fulfillment, privacy, and system availability) have been extensively used to measure the quality of E-shopping (Chiou \& Shen, 2006; Enzmann \& Schneider, 2005; Ribbink et al., 2004). Some researchers (Ribbink et al., 2004) posit that purchase intentions of E-shoppers can have long-haul sustained effects on customers' satisfaction and loyalty (Yu \& Lee, 2019). 
Parasuraman, Zeithaml, \& Malhotra (2005) studied the dimensions of ES-QUAL model and designed its scale. Jalilvand \& Samiei (2012) and Charo et al. (2015) investigated the impact of EWOM on brand image and purchase intention. Ahmed, Romeika, Kauliene, Streimikis, \& Dapkus (2020) ascertained ES-QUAL model's efficacy on customer satisfaction. Thus, there is a need to bridge this research gap by empirically examining the influence of ES-QUAL model on purchase intentions by examining the mediating effects of E-WOM and brand image in this context, which forms the basis and core objective of conducting this probe. This paper diffuses three models and contributes to the theory of service quality and ES-QUAL model in the contexts of online consumer behavior, online shopping, and ecommerce.

Purchase intention can be categorized as the decision in which we focus why a customer buys a product or brand online in particular. It is about how a customer prefers buying one product or brand over another to make a purchase. A customer focuses on specific brands and intends to purchase not only because of his/her attitude towards specific brands, but also focuses on other brands' features before making a choice (Porter, 1974). Engel et al. (1995) divided purchase intention into three layers of buying including unplanned, partially planned and fully planned. Unplanned buying can be defined as a consumer's plans to buy while s/he is in store (physically or virtually), which is also referred as the impulse buying. Partially planned buying is the decision of the customer in which s/he decides the category and specification of a product before making a purchase. Fully planned buying behavior refers to the customer who has already decided what brand, product or type with the specification and attributes s/he is going to buy. For sustainable business development, firms need to build goods or service brands with unique features, attributes and benefits, which should be available online too for the sake of convenience of the customers (Enache, 2015). Credibility of websites appears crucial for forming online purchase intentions (Siddiqui et al., 2021).

Online shopping has been fostering in Pakistan, but the quantity of users is yet beneath the world average, but people have some understanding of online shopping. According to experts, the reason why less people shop online is "payment mode", but as per an estimation, about $28 \%$ of the country's population will have access to the internet in coming five years. The electronic products like computers and cell phones are making $40 \%$ online sales, and this size seems to grow in future too. It is revealed that those retailers who have virtual and physical stores observed $23 \%$ growth in the business (Ahmed, 2015). The State Bank of Pakistan's payment system review in the year 2018, about 344 E-commerce merchants were registered in Pakistan and the number reached to 905 till the end of 2017, which points out the popular trend of online shopping (Khan, 2018). Most people living in the rural to urban areas of Pakistan have become familiar with online shopping and online banking, and have intentions to purchase online (Ahmed, et al., 2020; Baqai \& Qureshi, 2019). Jain and Sareen (2014) investigated various elements that affect online customer's behavior. The study recognized individual beliefs of the members of a society, technological environment, attitude of customers, and effort expectancy as essential factors, which alter customers' purchase 
intentions. Kushwah \& Bhargav (2014) studied young people's perceptions of online shopping and differences in their expectations. The results show that if someone wants to attract customers for online shopping, they need to work on websites to enhance the performance, so that they can bridge the gap between perceptions and expectations of people about online shopping.

Electronic service quality can be defined as customers' judgment and evaluation of E-service quality and how it delivers service to them. In connection with service quality theory (Hill, 1997), previously SERQUAL model which is a multi-item scale contained five dimensions, which include: tangibility, reliability, responsiveness, assurance and empathy. But afterwards, its validity was challenged because previously it was used for investigating customers' satisfaction for the service industry. Now the trends have been changed, online shopping has gained more attention and popularity; many people are moving towards online shopping instead of using that conventional mode of shopping. That is the reason, authors realized the need to upgrade SERQUAL model (Zeithaml, Parasuraman, Malhotra, 2002) with ES-QUAL model.

Parasuraman et al. (2005) introduced the ES-QUAL model in 2002 but Parasuraman $\&$ Zeithaml proposed its modified version in 2005. This model is basically used for measuring the service quality delivered by a website from where customer shops. First, they examined the ES-QUAL model by using a focus group in a qualitative study and found eleven dimensions, then they compressed and modified it, and came up with four dimensions only. They contain: Efficiency - this dimension can be defined as having easy-to-use, user-friendly, and speedy attributes of a website. Fulfillment - it is related to the fulfillment of promise about delivering the item. Privacy - this is the assurance that the website is free from any danger regarding protection of customers' information and transactions. System Availability - it is related to the technicality and practicality or functionality of the website (Ahmed, et al., 2020; Baqai \& Qureshi, 2019). If a website or web service is not efficient, does not fulfill its promise, for instance delivering goods on time, does not keep the customers' data confidential, and is not technically sound, the overall e-service quality will be affected, which generally translates into customer dissatisfaction and brand switching. Such conditions create negative perceptions of online consumers and global customers towards ecommerce and online shopping. ES-QUAL model has a linear relationship and effect on purchase intention (Ahmed, et al., 2020; Chang \& Liu 2009; Chen \& Hitt, 2002; Kenova \& Jonasson, 2006; Khalifa \& Shen, 2005; Parasuraman et al., 2002; Wenying \& Sun, 2010).

The extant literature indicates that E-service has a relationship with online purchase intention, so our proposed hypotheses for ES-QUAL model and purchase intention include:

H1. Efficiency has a positive and significant impact on purchase intention.

$\mathrm{H} 2$. Fulfillment has a positive and significant impact on purchase intention.

H3. Privacy has a positive and significant impact on purchase intention.

H4. System availability has a positive and significant impact on purchase intention. 
Recently the heavy usage and widespread popularity of social media sites for example, Google, Facebook, Yahoo, and Twitter completely altered word-of-mouth (WOM) communication into electronic word of mouth (E-WOM). Now it does not matter for individuals to share information face-to-face or electronically. EWOM is not only limited to friends' circle, it can be shared even with a wide audience on a platform, called social network. With the arrival of advanced technology, the reach of WOM has been extended in the form of EWOM. After having access to the internet facility of $3 \mathrm{G}$ and $4 \mathrm{G}$ in smartphones, now social networks have become necessities of life for everyone, and it has become a trend for customers to seek information on social sites before buying any product (Charo et al., 2015). In the context of EWOM/eWOM, opinion leaders, so-called influential marketers heavily influence public opinions (Zhou et al., 2019). To measure the effectiveness of Facebook advertising, it was uncovered that EWOM influenced purchase intention (Chetioui et al., 2021). The usage and efficacy of EWOM has been witnessed in various industries around the world, such as online shopping, online banking, booking of hotels, and digital commerce (Lee et al., 2021; Verma \& Yadav, 2021).

Many researchers have studied the effects of electronic word of mouth on purchase intention in different parts of the world. According to Henning-Thurau, et al. (2004), EWOM is considered as any negative or positive review or statement made by current or former customer or consumer about a product, service, or company, which is available to a large population to review before buying the product. Researchers are more concentrating in analyzing the motives for searching EWOM (Goldsmith \& Horowitz, 2006) and to share and express their opinions that have logical implications to marketers, so that they can understand in a better way about online customer behavior (Hennig-Thurau et al., 2004). Considering the scenario when consumers want to buy a product, they mostly seek information about quality, and with the help of internet search, information has become more frequent. EWOM in the form of online reviews is an essential source to get information about products' quality and in several cases, it builds customer loyalty (Gruen et al., 2006). According to one survey conducted by Comscore (an internet marketing research company), it found that about $24 \%$ are those who check online reviews and give importance to offline service delivery; and firms are increasing in number that concentrates on online mode and enjoying its benefits (Dellarocas, 2003).

By the end of 2020, the Internet users in the country reached to 44.6 million (Pakistan Advertising Society, 2020). It is estimated that 20.6\% of Pakistan's population used social media (Datareportal, 2021). Pakistan's social media introduced an attractive scenario for different firms and brands to take advantage of this platform. As per one estimation, about $60 \%$ of those who used the internet interacted with brands only and around $53 \%$ out of total users on social media used Facebook. The total number is increasing quarterly as in Pakistan one out of five Facebook users made decisions induced by Facebook ads (Pakistan Advertising Society, 2020). With the heavily increased usage of social networks, consumers are more aware about different choices and EWOM is playing a pivotal role in it. The digital customer-brand engagement has further corroborated the relationship between companies and customers (Eigenraam et al., 2018), which strengthens global ecommerce. 
Hence, on the basis of extant literature, our hypotheses include:

H5. Electronic word of mouth mediates the relationship between efficiency and purchase intention.

H6. Electronic word of mouth mediates the relationship between fulfillment and purchase intention.

H7. Electronic word of mouth mediates the relationship between privacy and purchase intention.

H8. Electronic word of mouth mediates the relationship between system availability and purchase intention.

H9. Electronic word of mouth has a positive and significant impact on purchase intention.

Brand image can be defined as the perception of a consumer regarding a specific brand that what image s/he possesses in mind about it. A consumer interprets a brand's image on the basis of the personality of a brand. It takes time to be developed; it depends whether it develops through advertisements or publicity or with the personal usage experience of consumers (Aaker, 1996). According to previous studies, Wu \& Lo (2009), a consumer perceives a brand subjectively and/or objectively. They perceive a brand's image objectively by seeing its promotional activity cost, its market share, and strong distribution channel, then on that basis consumers consider a brand as inferior or superior. While they perceive a brand subjectively by seeing its advertising and other communication messages, they develop feelings and opinions based on their experiences. Regarding brand image, Jalilvand \& Samiei (2012) thought that the customer is not buying only the product/service, but s/he also has the image associated with that product/ service. Brand images must be positive, different, and even instant. Brand image has the ability to strengthen a brand with the help of brand communications for instance, advertising, packaging, word of mouth publicity, and other promotional tools. Siddiqui, et al. (2021) found that the credibility of social media websites plays a salient role in developing brand image and online purchase intention. The brand experience paves the way for building brand image and brand love (Joshi \& Garg, 2021).

Globally, firms have tremendously invested for the creations and development of the brand. Creating a brand means creating an image of the brand in a unique way that the entire firm's competitors associate with that brand. Aaker (1991) defined brand equity as "a set of brand assets and liabilities linked to a brand, its name and symbol that add to or subtract from the value provided by a product or service to a firm and/or to that firm's customers". After Aaker's study, Keller (1993) also built a behavioral concept that was about customer-based brand equity (CBBE). He emphasized on brand awareness and brand image's dimensions explained that customers' responses vary according to knowledge about a brand, and this knowledge differs from person to person. On the basis of that knowledge, each brand contains some benefits and attributes with it and these assist consumers in distinguishing one brand from the other. According to Keller \& Lehmann (2006), attributes are basically the features that portray a brand in a way 
that they want their consumers to perceive it. Benefits are an individual's values that connect to the brand attributes, or in other words what a consumer perceives a brand could do for him/her. In the customer relationship of every firm, customers turn into an input for a brand image. Firms keep a close eye on their customers and maintain close relationships with them through communication and commit to provide valuable experiences. They need to pay attention to assure that each and every individual in the firm must understand to deliver consistent and good quality service to the customers (Webster \& Keller, 2004). Sometimes customers become disappointed if a firm fails to fulfill customers' expectations. Therefore, customers generally trust those product or service providers who continuously provide them high quality product and improve the quality with passage of time (Cousins \& Menguc, 2006). Shukla (2010) analyzed that brand cues also play a central role in shaping up a customer's purchase intention.

Hence, on the basis of extant literature, our hypotheses include:

H10. Brand image mediates the relationship between efficiency and purchase intention. H11. Brand image mediates the relationship between fulfillment and purchase intention. H12. Brand image mediates the relationship between privacy and purchase intention.

H13. Brand image mediates the relationship between system availability on purchase intention. H14. Brand image has a positive and significant impact on purchase intention.

The conceptual framework is connecting the ES-QUAL model with the purchase intention, and adding EWOM and brand image into the framework as mediating variables for testing the relationships through hypotheses, which is exhibited in Figure 1 (portrayed in two ways). The model is taken from the study of Jalilvand \& Samiei (2012) and is expanded and diffused with the models of Ahmed, et al. (2020) and Parasuraman, et al., (2005).

Figure 1. Conceptual Framework (portrayed in two ways)

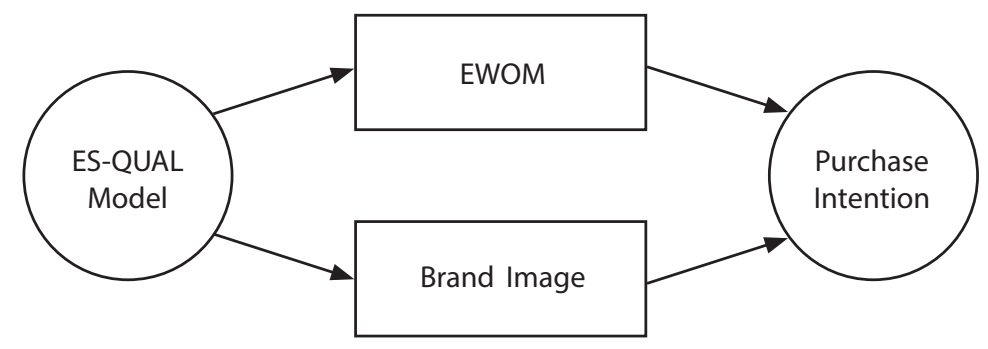

\section{ES-QUAL Variables:}

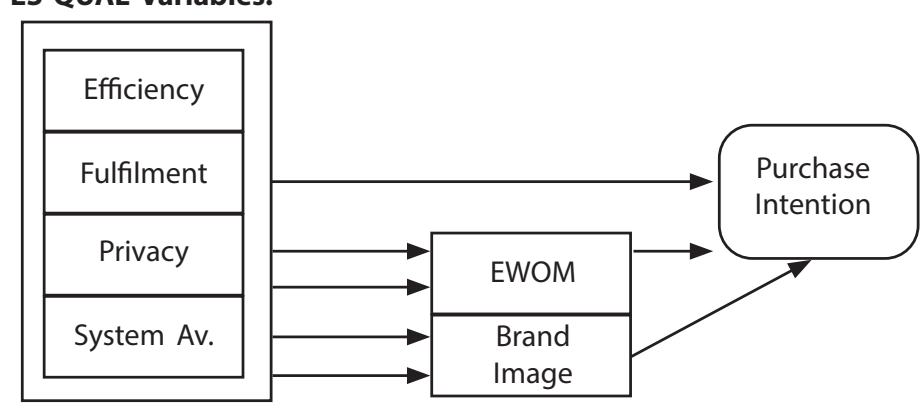

Source: Adapted from: (Ahmed, et al., 2020; Jalilvand \& Samiei 2012; Parasuraman, et al. 2005) 


\section{Methods}

The post-positivist philosophy is used as research philosophy since theories are employed to test the relationship between the variables. Therefore, the deductive approach of quantitative research methodology is employed in this study. Data was collected through a close-ended and structured questionnaire for the survey to take pertinent insights. The questionnaire was adapted from Jalilvand \& Samiei (2012) study and was diffused with the ES-QUAL model's instrument/scale by Parasuraman et al. (2005). The efficiency dimension contains eight items in the ES-QUAL model, whereas fulfillment, system availability, and privacy contain 7, 4, and 3 items, respectively (i.e., total 22 items). EWOM and brand image are mediating variables, containing 3 and 6 items sequentially, and purchase intentions. The dependent variable contains three items, which makes overall 34 items. A five-point Likert scale is used.

According to the Pakistan internet usage report from the World Bank sources (Global Economy, 2017); by the end of 2020, it reached 44.6 million (Pakistan Advertising Society, 2020), but there is no estimate available for Karachi users. As youth is considered to be more tech-savvy and inclined towards online shopping and e-commerce, we have taken youth as the respondents. People living in Karachi with access to the Internet regardless of their gender, age, education, and professions are the population of this study. The unit of analysis includes all the individuals who use online reviews before engaging in online shopping. Due to the lack of availability of a sampling frame or structured data about samples, the convenience method of non-probability sampling is employed, which is a limitation of this study. Our sample size was 325, which was determined by using the formula $\mathrm{Nx} 30$, i.e., the number of variables multiplied by 30 samples (Sekaran $\&$ Bougie, 2016), which became 120, but we surveyed 325 respondents.

A pilot study using 46 questionnaires was conducted, and ten questionnaires were unused as they contained more than 50 percent missing values. After confirming reliability and validity tests, we conducted a survey and analyzed the data. SPSS and PLS software were utilized for data analysis. SPSS was used to deal with the missing values and to track the participants' demographics. PLS assisted in predicting the relationship among pertinent constructs. Several authors recommended preferring SmartPLS software when the data is not normal and/or the sample size is small. Although our sample size of 325 is considered good, it is not a very large sample. Therefore, we used PLS-SEM according to the guidelines (Reinartz et al., 2009; Rigdon, 2016).

\section{Result and Discussion}

The structural equation modelling (SEM) was employed on PLS software for empirically testing our hypotheses. While assessing the measurement model, Confirmatory factor analysis (CFA) technique was applied, which is a factor reduction technique that identifies strong factors in the model, while the weak ones are eliminated. The data normality test found that Skewness and Kurtosis for each construct appeared within the range of \pm 1.5 , which indicate that there is no issue of univariate normality of constructs. In CFA 
analysis, some items with loadings less than .5 and insignificant $T$ values were deleted, and only significant factors with loadings greater than .7 were kept (Byrne, 2013; Hair Jr et al., 2015).

Figure 2. Measurement Model

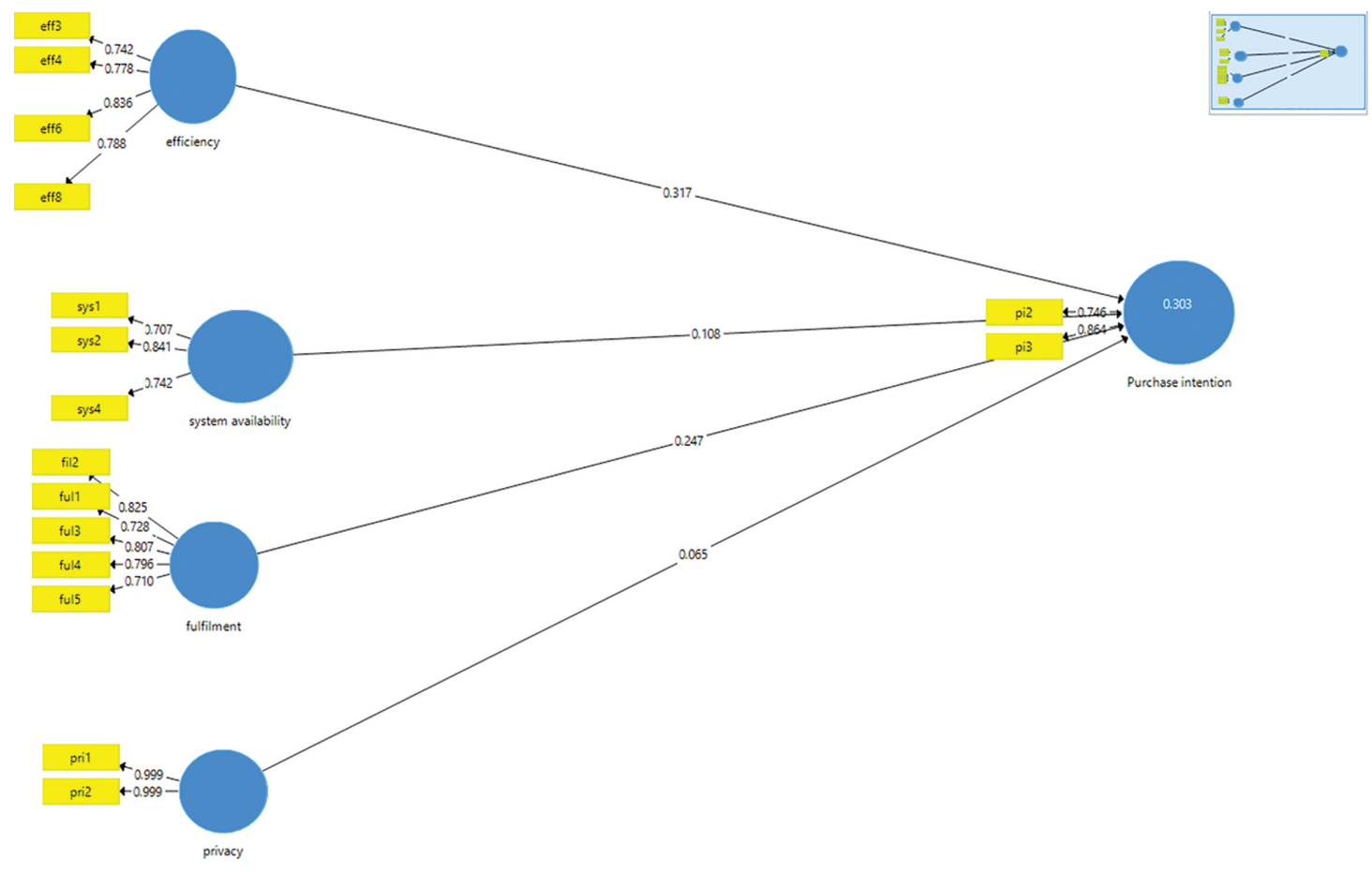

In Table 1, alpha and composite reliability (CR) values fall greater than the cut off value of .7, whereas the values of average variance extracted (AVE) fall greater than .5 . About constructs validity, convergent validity suggests that all the measures of a construct or all variables theoretically correlate. These values appear greater than the benchmark of .40. Non-convergent or discriminant validity shows shared validity between pairs of constructs fell within the range of 0.05 to 0.45 , which should be less than AVE of each construct, and it fell within the range of 0.51 to 0.61 (Hair Jr et al., 2010; Marsh, Morin, Parker, \& Kaur, 2014). The individual item loadings of all the constructs, obtained through the measurement model, are present in Figure 2 and Table 1. The Figure 2 displays the measurement model with direct relations and factor loadings of the predictors and outcome variables.

Using SmartPLS bootstrapping method performed the structural model assessment. It analyzed the direct relationships by considering t-values and path coefficients among all the variables and then, the mediating relationships. The output is displayed in Figure 3 and Table 2. Table 2 shows the direct effect. The results indicate that the predicting variables have a positive and significant effect/relationship with the outcome variable and had t-values more than 1.96 and p-values below 0.05. Efficiency has a positive and significant effect on purchase intention $(\mathrm{t}=2.510, p<0.010)$. Then, fulfillment and system availability also have positive and significant effects on purchase intention 
$(\mathrm{t}=2.210, p<0.010 ; \mathrm{t}=2.101, p<0.020)$. Privacy does not have a positive and significant effect on purchase intention $(\mathrm{t}=0.081, p<0.071)$. Thus, hypotheses H1, $\mathrm{H} 2$, and $\mathrm{H} 4$ are supported, whereas $\mathrm{H} 3$ is not supported. EWOM has a positive and significant mediating effect on purchase intention ( $\mathrm{t}=2.620, p<0.010)$. Thus, H9 is supported. Brand image has a positive and significant effect on purchase intention $(\mathrm{t}=$ 2.910, $p<0.000)$. Thus, H14 is supported.

Table 1. Reliabilities and Validities $(\mathrm{N}=325)$

\begin{tabular}{|c|c|c|c|c|c|c|c|}
\hline Indicators & Efficiency & Fulfillment & $\begin{array}{c}\text { System } \\
\text { Availability }\end{array}$ & Privacy & EWOM & $\begin{array}{l}\text { Brand } \\
\text { Image }\end{array}$ & $\begin{array}{l}\text { Purchase } \\
\text { Intention }\end{array}$ \\
\hline Efficiency3 & .742 & & & & & & \\
\hline Efficiency4 & .778 & & & & & & \\
\hline Efficiency6 & .836 & & & & & & \\
\hline Efficiency8 & .788 & & & & & & \\
\hline Fulfillment1 & & .825 & & & & & \\
\hline Fulfillment2 & & .728 & & & & & \\
\hline Fulfillment3 & & .807 & & & & & \\
\hline Fulfillment4 & & .796 & & & & & \\
\hline Fulfillment5 & & .710 & & & & & \\
\hline System Av.1 & & & .707 & & & & \\
\hline System Av.2 & & & .841 & & & & \\
\hline System Av.4 & & & .742 & & & & \\
\hline Privacy 1 & & & & .999 & & & \\
\hline Privacy 2 & & & & .999 & & & \\
\hline EWOM1 & & & & & .814 & & \\
\hline EWOM2 & & & & & .861 & & \\
\hline EWOM6 & & & & & .822 & & \\
\hline $\begin{array}{l}\text { Brand } \\
\text { Image2 }\end{array}$ & & & & & & .810 & \\
\hline $\begin{array}{l}\text { Brand } \\
\text { Image3 }\end{array}$ & & & & & & .805 & \\
\hline $\begin{array}{l}\text { Purchase } \\
\text { Int.1 }\end{array}$ & & & & & & & .715 \\
\hline $\begin{array}{l}\text { Purchase } \\
\text { Int. } 2\end{array}$ & & & & & & & .746 \\
\hline $\begin{array}{l}\text { Purchase } \\
\text { Int.3 }\end{array}$ & & & & & & & .864 \\
\hline Alpha (a) & .821 & .853 & .831 & .835 & .811 & .820 & .841 \\
\hline AVE & .510 & .557 & .580 & .615 & .521 & .534 & .540 \\
\hline CR & .861 & .882 & .890 & .875 & .831 & .851 & .878 \\
\hline
\end{tabular}


Figure 3. Structural Model Assessment

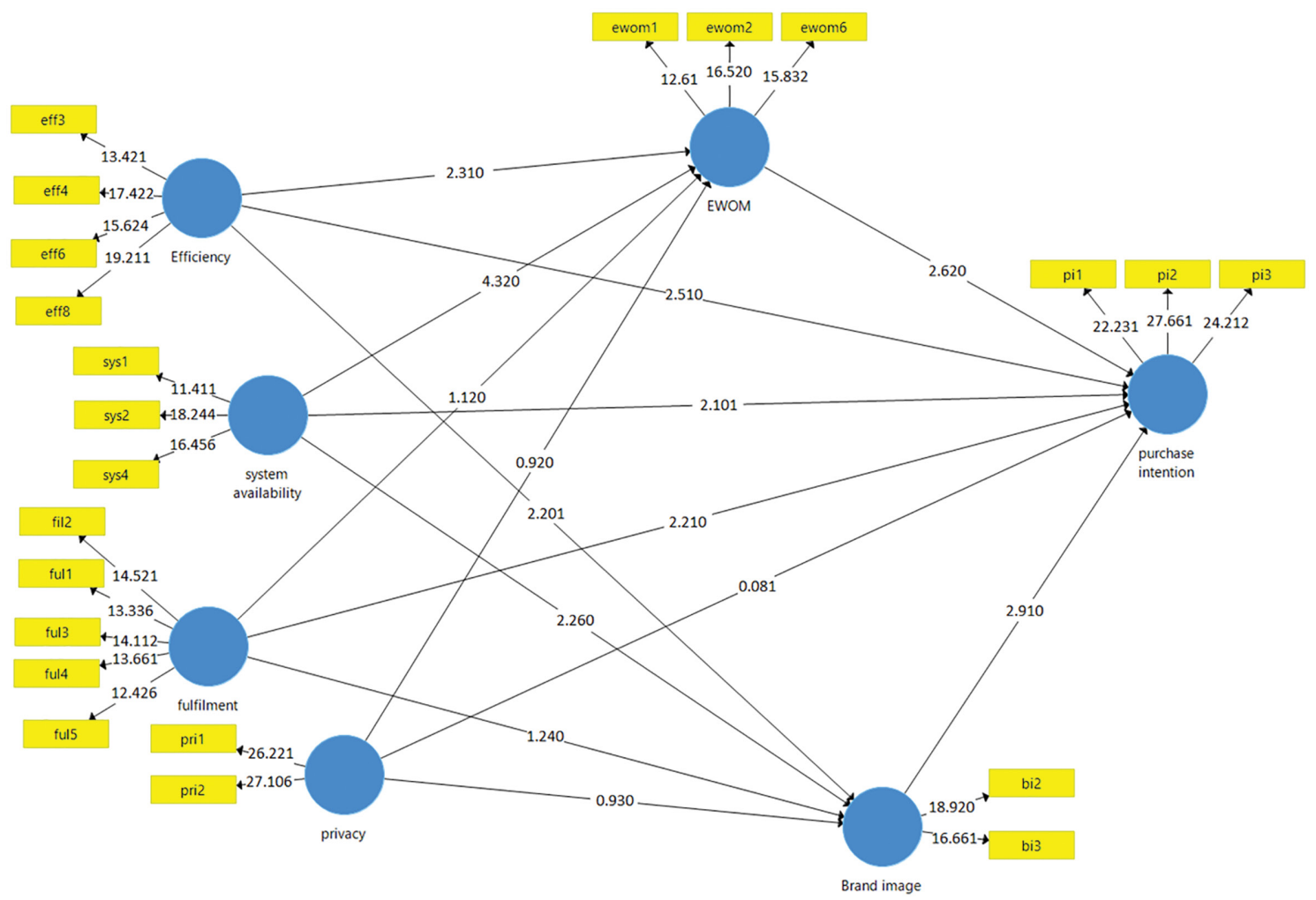

Table 4 shows the indirect effect examined through resampling mediation technique. The results show that EWOM mediates between the relationship of efficiency and purchase intention $(t=2.310, p<0.001)$. Then, EWOM mediates between the relationship of system availability and purchase intention $(\mathrm{t}=4.320, p<0.00)$. EWOM does not mediate between the relationship of fulfillment and purchase intention as well as privacy and purchase intention $(\mathrm{t}=1.120, p<0.070 ; \mathrm{t}=-0.920, p<0.090)$. Thus, hypotheses H5 and $\mathrm{H} 7$ are supported, whereas $\mathrm{H} 6$ and $\mathrm{H} 8$ are not supported. Regarding the second mediating variable, brand image mediates between efficiency and purchase intention ( $\mathrm{t}$ $=2.201, p<0.010)$. Then, brand image mediates the relationship of between system availability and purchase intention $(\mathrm{t}=2.260, p<0.001)$. Brand image does not mediate between the relationship of fulfillment as well as privacy and purchase intention $(\mathrm{t}=$ 1.240, $p<0.070 ; \mathrm{t}=0.930, p<0.090)$. Brand image has a positive and significant effect on purchase intention $(\mathrm{t}=2.91, p<0.01)$. Thus, hypotheses H10 and H12 are supported, whereas $\mathrm{H} 11$ and $\mathrm{H} 13$ are not supported. Brand image has a positive and significant effect on purchase intention $(\mathrm{t}=2.91, p<0.01)$. Thus, H14 is supported. The original sample mean and sample mean fall within the range of .029 to 0.334 and 0.221 to 0.376 respectively. The standard deviation falls within the range of 0.112 to 0.1.61. All the variables have moderate effect size denoted by $\mathrm{f}^{2}$, which ranges between 0.15 until 0.34 . 
Table 2. Structural Model Assessment (Direct Effect)

\begin{tabular}{|c|c|c|c|c|c|}
\hline \multicolumn{3}{|c|}{ Path Coefficients } & \multirow{2}{*}{$\frac{\text { t Statistics }}{2.510}$} & \multirow{2}{*}{$\frac{\text { P Values }}{0.010}$} & \multirow{2}{*}{$\frac{\text { Supported or not }}{\text { Supported }}$} \\
\hline Efficiency & $\rightarrow$ & Purchase Intention & & & \\
\hline Fulfillment & $\rightarrow$ & Purchase Intention & 2.210 & 0.010 & Supported \\
\hline Privacy & $\rightarrow$ & Purchase Intention & 0.081 & 0.071 & Not Supported \\
\hline System Availability & $\rightarrow$ & Purchase Intention & 2.101 & 0.020 & Supported \\
\hline EWOM & $\rightarrow$ & Purchase Intention & 2.620 & 0.010 & Supported \\
\hline Brand Image & $\rightarrow$ & Purchase Intention & 2.910 & 0.000 & Supported \\
\hline
\end{tabular}

Directly ES-QUAL model had 27\% impact, but once we introduced EWOM and brand image as mediating variables, the explaining power jumped to $44 \%$ (see Table 3 ). The value above .33 is considered substantial. Table 4 displays standardized regression coefficients of the constructs.

Table 3. R-Square $\left(\mathbf{R}^{2}\right)$ Value

\begin{tabular}{cccccc}
\hline $\begin{array}{c}\text { Direct } \\
\text { Relationship }\end{array}$ & R-Square & $\begin{array}{c}\text { Adj. } \\
\text { R-Square }\end{array}$ & $\begin{array}{c}\text { Indirect } \\
\text { Relation }\end{array}$ & R-Square & Adj. R-Square \\
\hline Purchase intention & .303 & .273 & Brand Image & .194 & .159 \\
& & & EWOM & .220 & .186 \\
& & $\begin{array}{l}\text { Purchase } \\
\text { intention }\end{array}$ & .447 & .410 \\
\hline
\end{tabular}

First, we estimated the model with an independent variable (the ES-QUAL model's four dimensions) and the dependent variable (purchase intention) to test the four hypotheses, and found that the dimensions, efficiency, fulfillment, and system availability have a direct effect on purchase intention. The aggregate results appear consistent with the extant literature but also differ in some way due to indigenous contextual differences, Pakistan is an emerging market where ecommerce is a relatively new phenomenon. The variables of the ES-QUAL model, efficiency, fulfillment, and system availability appear to be positive and significant predictors of purchase intention, but privacy is not significant. Sequentially, efficiency, fulfillment, and system availability are the strong predictors of purchase intention.

Both mediating variables, EWOM and brand image have positive and significant relationship/effect on purchase intention. But regarding the mediating effect of EWOM with the variables of the ES-QUAL model, efficiency and system availability appear positively significant, whereas fulfillment and privacy appear vice versa, which is also the case with the brand image. In estimating the mediating effect of brand image, a positively significant effect is found with efficiency and system availability, whereas fulfillment and privacy have insignificant relationship. 
Table 4. Structural Model Assessment (Indirect Effect)

\begin{tabular}{lllccc}
\hline & \multicolumn{2}{l}{ Path Coefficients } & T Statistics & P Values & $\begin{array}{c}\text { Decision of } \\
\text { Mediation }\end{array}$ \\
\hline Efficiency $\rightarrow$ & EWOM $\rightarrow$ & Purchase Intention & 2.310 & 0.001 & Mediation \\
Fulfillment $\rightarrow$ & EWOM $\rightarrow \quad$ Purchase Intention & 1.120 & 0.070 & No Mediation \\
Privacy $\rightarrow$ & EWOM $\rightarrow$ & Purchase Intention & 0.920 & 0.090 & No Mediation \\
System Av. $\rightarrow$ & EWOM $\rightarrow$ & Purchase Intention & 4.320 & 0.000 & Mediation \\
Efficiency $\rightarrow$ & Brand I. $\rightarrow$ & Purchase Intention & 2.201 & 0.010 & Mediation \\
Fulfillment $\rightarrow$ & Brand I. $\rightarrow$ & Purchase Intention & 1.240 & 0.070 & No Mediation \\
Privacy $\rightarrow$ & Brand I. $\rightarrow$ & Purchase Intention & 0.930 & 0.090 & No Mediation \\
System Av. $\rightarrow$ & Brand I. $\rightarrow$ & Purchase Intention & 2.260 & 0.001 & Mediation \\
\hline
\end{tabular}

The three dimensions out of four corroborate that the ES-QUAL model has a positive impact on purchase intention, which support the previous studies (Chang \& Liu 2009; Chen \& Hitt, 2002; Kenova \& Jonasson, 2006; Khalifa \& Shen, 2005; Parasuraman et al., 2005; Wenying \& Sun, 2010). This condition could lead to customer satisfaction (Ahmed et al., 2020; Duarte et al., 2018; Dash et al., 2021) and loyalty (Yu \& Lee, 2019). This condition will affect customer loyalty (Yoo et al., 2013; Tran \& Strutton, 2020).

Once we tested the direct impact, we moved towards analyzing the relationship between the ES-QUAL model and purchase intention by keeping EWOM and brand image as mediating variables. The results of the mediating variables support a previous study that EWOM and brand image have a positive impact on purchase intention (Baqai \& Qureshi, 2019; Jalilvand \& Samiei, 2012; Siddiqui et al., 2021; Sun et al., 2021) show that e-WOM influences consumer ethnocentrism, and these effects are contingent upon brand origin.

\section{Conclusion}

The core research problem and purpose tried to unearth the impact of the ESQUAL model on online purchase intention by using SEM multivariate approach. First, we assessed the direct relationship or impact of all four dimensions of the ES-QUAL with purchase intention, and then, by keeping brand image and EWOM as mediating variables, we tested these relationships. The results reveal the positive and significant relationship between the ES-QUAL model's three dimensions (efficiency, fulfillment, and system availability) and purchase intention, except privacy that observed an insignificant effect. Efficiency, fulfillment, and system availability are respectively the strong predictors of purchase intention. EWOM and brand image mediates the relationship of purchase intention. EWOM and brand image positively and significantly mediate the relationship between the ES-QUAL model's dimensions, efficiency, and system availability, but this is not the fact regarding fulfillment and privacy that have insignificant effects. 
The results and analysis reflect the local indigenous context, meaning that contextual differences exist in different countries. Our analysis concluded and substantiated that the ES-QUAL model can be applied in the context of Pakistan to improve the online purchase intention of customers, which can lead to more significant sales, exports, profitability, and customers' satisfaction to loyalty and business sustainability. For sustainable business development, businesses need to focus on quality, innovative attributes that make their brands unique, stylish or differentiated, make them available online, and add features that provide customers with a wide range of options. Digital marketers need to develop easy-to-use, user-friendly, and speedy attributes of a technically excellent or functional website. They need to fulfill their promise of delivering the appropriate products on time and in a transparent way and should ensure pre-sales and post-sales services. Moreover, it will assist in nurturing a well-established e-commerce marketplace in the country, which could substantially benefit the local economy in the form of a collection of tax revenues to the exchequer, will enhance its capability to compete well in the global markets, and raise its market share in the global e-commerce. However, this mandatorily requires improving the overall quality and innovative features of products, brands, and overall electronic services.

The results demonstrated that marketers and entrepreneurs engaged in the online business should focus on improving the quality of their websites as online shoppers are increasing daily, and they want an effective delivery system. They like to visit websites that are easy-to-use and always have stock available. If the stock falls short, they get disappointed, which would affect any online business. The e-commerce firms should strategize to have an effective transaction system, which does not create problems for customers to make payments for their desired products and brands. In addition, they need to encourage and motivate consumers to share their experiences regarding the brands on online portals. This condition could motivate potential customers to share their views, which can inspire others or provide hints to the online players for their shortcomings and areas of improvement. Consequently, they would get insights, which appear substantially helpful for them towards brand building. If they establish positive electronic word-of-mouth (EWOM) communication, it will reduce marketing outlays. They also need to concentrate on their existing satisfied and loyal customers as their positive EWOM leads to sustainable business.

This probe appears to be limited in methodological design, sample size and method, and variables. Due to any sampling frame's unavailability, we used a convenient sampling method, which is not suitable for generalizing results. We took a variable, brand image, related to attitudinal and behavioral measures, while EWOM also reflects such measures. For future studies, it will be helpful if our expanded model could add more variables like more attitudinal and behavioral dimensions to get consumers' insights for improving purchase intention. 


\section{References}

Aaker, D.A. (1991). Managing Brand Equity. The Free Press. New York, NY.

Aaker, D. A. (1996). Building Strong Brands. The Free Press. New York.

Ahmed, J. (2015). The encouraging future of e-commerce in Pakistan. The Express Tribune. Retrieved from: https://tribune.com.pk/story/975430/the-encouraging-futureof-e- commerce-in-pakistan

Ahmed, R. R., Romeika, G., Kauliene, R., Streimikis, J., \& Dapkus, R. (2020). ES-QUAL Model and Customer Satisfaction in Online Banking: Evidence From Multivariate Analysis Techniques. Oeconomia Copernicana, 11(1), 59-93.

Baron, R. M., \& Kenny, D. A. (1986). The Moderator-mediator Variable Distinction in Social Psychological Research: Conceptual, Strategic, and Statistical Considerations. Journal of personality and social psychology, 51(6), 1173-1182.

Baqai, S. \& Qureshi, J. A. (2019). ES-QUAL Model and Customer Satisfaction on Online Purchase: Evidence Using Component Based Analysis. Proceedings of 15th South Asian Management Forum, 2019, Sukkur IBA.

Baqai, S. \& Qureshi, J. A. (2020). Data as a Competitive Weapon in The DigitalGlobalization Era: An Empirical Inquiry on Marketing Analytics Using Multivariate Analysis. Journal of Estudios de Economia Applicada, 38(3), 211-220. https://doi. org/10.25115/eea.v38i3.3368.

Bashir, R., Mehboob, I., \& Bhatti, W. K. (2015). Effects of Online Shopping Trends on Consumer-Buying Behavior: An Empirical Study of Pakistan. Journal of Management and Research, 2(2), 1-24. https://doi.org/10.29145/jmr/22/0202001.

Bashir, S., Syed, S. \& Qureshi, J.A. (2017). Philosophical and Methodological Aspects of Mixed-Methods Research: A Review of the Academic Literature. Journal of Independent Studies and Research, 15(1), 32-50.

Byrne, B. M. (2013). Structural Equation Modeling with AMOS: Basic Concepts, Applications, and Programming. Routledge. New York.

Chang, H. H., \& Liu, Y. M. (2009). The Impact of Brand Equity on Brand Preference and Purchase Intentions in The Service Industries. The Service Industries Journal, 29(12), 1687-1706.

Charo, N., Sharma, P., Shaikh, S., Haseeb, A., \& Sufya, M. Z. (2015). Determining The Impact of EWOM on Brand Image and Purchase Intention Through Adoption of Online Opinions. International Journal of Humanities and Management Sciences, 3(1), 41-46.

Chen, P. Y., \& Hitt, L. (2002). Measuring Switching Costs and Their Determinants in Internet Enabled Businesses: A Study of the Online Brokerage Industry. Information Systems Research, 13(3), 255-276.

Chetioui, Y., Butt, I., \& Lebdaoui, H. (2021). Facebook Advertising, eWOM and Consumer Purchase Intention-Evidence From a Collectivistic Emerging Market. Journal of Global Marketing, 34(3), 220-237. https://doi.org/10.1080/08911762.2021.1891359. 
Chiou, J. S., \& Shen, C. C. (2006). The Effects of Satisfaction, Opportunism, and Asset Specificity on Consumers' Loyalty Intention Toward Internet Portal Sites. International Journal of Service Industry Management, 17(1), 7-22. https://doi.org/10.1108/095642306 10651552.

Cousins, P. D., \& Menguc, B. (2006). The Implications of Socialization and Integration in Supply Chain Management. Journal of Operations Management, 24(5), 604-620. https://doi.org/10.1016/j.jom.2005.09.001.

Dash, G., Kiefer, K., \& Paul, J. (2021). Marketing-to-Millennials: Marketing 4.0, Customer Satisfaction and Purchase Intention. Journal of Business Research, 122, 608-620. https://doi.org/10.1016/j.jbusres.2020.10.016.

Datareportal. (2021). Digital 2021: Pakistan. https://datareportal.com/reports/digital-2021pakistan

Dellarocas, C. (2003). The Digitization of Word of Mouth: Promise and Challenges of Online Feedback Mechanisms. Management Science, 49(10), 1407-1424. https://doi. org/10.1287/mnsc.49.10.1407.17308.

Duarte, P., e Silva, S. C., \& Ferreira, M. B. (2018). How Convenient is it? Delivering Online Shopping Convenience to Enhance Customer Satisfaction and Encourage e-WOM. Journal of Retailing and Consumer Service, 44, 161-169. https://doi. org/10.1016/ j.jretconser.2018.06.007.

Eigenraam, A. W., Eelen, J., Van-Lin, A., \& Verlegh, P. W. (2018). A ConsumerBased Taxonomy of Digital Customer Engagement Practices. Journal of Interactive Marketing, 44, 102-121. https://doi.org/10.1016/j.intmar.2018.07.002.

Enache, I. C. (2015). Connecting Customers' Satisfaction to Sustainable Development. A Marketing Models Perspective. Bulletin of the Transilvania University of Brasov, Series V: Economic Sciences, 8(57), 51-56.

Enzmann, M., \& Schneider, M. (2005). Improving Customer Retention in E-commerce Through a Secure and Privacy-Enhanced Loyalty System. Information Systems Frontiers, 7(4-5), 359-370.

Ghosh, M. (2018). Measuring Electronic Service Quality in India Using ES-QUAL. International Journal of Quality \& Reliability Management, 35(2), 430-445. https:// doi.org/10.1108/IJQRM-07-2016-0101.

Goldsmith, R. E., \& Horowitz, D. (2006). Measuring Motivations for Online Opinion Seeking. Journal of Interactive Advertising, 6(2), 2-14. https://doi.org/10.1080/1525 2019.2006.10722114.

Gruen, T. W., Osmonbekov, T., \& Czaplewski, A. J. (2006). eWOM: The Impact of Customer-to-Customer Online Know-how Exchange on Customer Value and Loyalty. Journal of Business Research, 59(4), 449-456. https://doi.org/10.1016/j.jbusres. 2005. 10.004.

Hair Jr, J., Black, W., Babin, B., Anderson, R., \& Tatham, R. (2010). Multivariate Data Analysis. Pearson Education. New Jersey. 
Hair, J. F., Jr., Money, A. H., Samouel, P., \& Page, M. (2007). Research Methods for Business. Wiley. New Jersey.

Hair Jr, J. F., Wolfinbarger, M., Money, A. H., Samouel, P., \& Page, M. J. (2015). Essentials of Business Research Methods. Routledge.

Hennig-Thurau, T., Gwinner, K. P., Walsh, G., \& Gremler, D. D. (2004). Electronic Word-of-Mouth via Consumer-Opinion Platforms: What Motivates Consumers to Articulate Themselves on The Internet?. Journal of Interactive Marketing, 18(1), 3852. https://doi.org/10.1002/dir.10073.

Herold, D. M., Cwiklicki, M., Pilch, K., \& Mikl, J. (2021). The Emergence and Adoption of Digitalization in The Logistics and Supply Chain Industry: An Institutional Perspective. Journal of Enterprise Information Management, In-press. https://doi. org/10.1108/JEIM-09-2020-0382.

Hill, F. (1997). The Implications of Service Quality Theory for British Higher Education: An Exploratory Longitudinal Study. The Journal of General Education, 46(3), 207-231.

Jain, A., \& Sareen, M. (2015). Antecedents of E-loyalty Towards Online Shopping: An Empirical Analysis of Indian Online Customers. International Journal of Research in IT \& Management, 5(9), 1-14.

Jalilvand, R. M., \& Samiei, N. (2012). The Effect of Electronic Word of Mouth on Brand Image and Purchase Intention: An Empirical Study in The Automobile Industry in Iran. Marketing Intelligence \& Planning, 30(4), 460-476.

Joshi, R., \& Garg, P. (2020). Role of Brand Experience in Shaping Brand Love. International Journal of Consumer Studies, 45(2), 259-272. https://doi.org/10.1111/ ijcs. 12618.

Keller, K. L. (1993). Conceptualizing, Measuring, and Managing Customer-Based Brand Equity. Journal of Marketing, 57(1), 1-22.

Keller, K. L., \& Lehmann, D. R. (2006). Brands and Branding: Research Findings and Future Priorities. Marketing Science, 25(6), 740-759.

Kenova V. \& Jonasson P. (2006). Quality Online Banking Services. (Unpublished Thesis). Jonkoping International Business School, Sweden.

Khalifa, M., \& Shen, N. (2005). Effects of Electronic Customer Relationship Management on Customer Satisfaction: A Temporal Model. Proceedings of the 38th Annual Hawaii International Conference on System Sciences.

Kushwah, S. V., \& Bhargav, A. (2014). Service Quality Expectations and Perceptions of Telecom Sector in India. International Journal of Advancements in Technology, 5(1), $1-10$.

Lee, H., Min, J., \& Yuan, J. (2021). The Influence of eWOM on Intentions for Booking Luxury Hotels by Generation Y. Journal of Vacation Marketing, 27(3), 237-251. https://doi.org/10.1177/1356766720987872. 
Marsh, H. W., Morin, A. J., Parker, P. D., \& Kaur, G. (2014). Exploratory structural equation modeling: An integration of the best features of exploratory and confirmatory factor analysis. Annual review of clinical psychology, 10(1), 85-110.

Marsh, H. W., Morin, A. J., Parker, P. D., \& Kaur, G. (2014). Exploratory Structural Equation Modeling: An Integration of The Best Features of Exploratory and Confirmatory Factor Analysis. Annual Review of Clinical Psychology, 10(1), $85-110$.

Nagra, G., \& Gopal, R. (2013). A Study of Factors Affecting on Online Shopping Behaviour of Consumers. International Journal of Scientific and Research Publications, 3(6), 1-4.

Pakistan Advertising Society. (2020). The number of Internet users in Pakistan. https:// pas.org.pk/

Pakistan Internet Usage and Telecommunications Reports. (2019). Retrieved from https:// www.internetworldstats.com/asia/pk.htm

Parasuraman, A., Zeithaml, V. A., \& Malhotra, A. (2005). ES-QUAL: A Multiple-Item Scale for Assessing Electronic Service Quality. Journal of Service Research, 7(3), 213233. https://doi.org/10.1177/1094670504271156.

Porter, M. E. (1974). Consumer Behavior, Retailer Power and Market Performance in Consumer Goods Industries. The Review of Economics and Statistics, 56(4), 419-436. https://doi.org/10.2307/1924458.

Reinartz, W. J., Haenlein, M., \& Henseler, J. (2009). An Empirical Comparison of The Efficacy of Covariance-based and Variance-based SEM. International Journal of Research in Marketing, 26(4), 332-344.

Ribbink, D., Van Riel, A. C., Liljander, V., \& Streukens, S. (2004). Comfort Your Online Customer: Quality, Trust and Loyalty on The Internet. Managing Service Quality: An International Journal, 14(6), 446-456.

Rigdon, E. E. (2016). Choosing PLS Path Modeling as Analytical Method in European Management Research: a Realist Perspective. European Management Journal, 34(6), 598-605. https://doi.org/10.1016/j.emj.2016.05.006.

Sekaran, U., \& Bougie, R. (2016). Research Methods for Business: A Skill Building Approach. John Wiley \& Sons. New Jersey.

Shukla, P. (2011). Impact of Interpersonal Influences, Brand Origin and Brand Image on Luxury Purchase Intentions: Measuring Interfunctional Interactions and a CrossNational Comparison. Journal of World Business, 46(2), 242-252.

Siddiqui, M. S., Siddiqui, U. A., Khan, M. A., Alkandi, I. G., Saxena, A. K., \& Siddiqui, J. H. (2021). Creating Electronic Word of Mouth Credibility through Social Networking Sites and Determining Its Impact on Brand Image and Online Purchase Intentions in India. Journal of Theoretical and Applied Electronic Commerce Research, 16(4), 1008-1024. https://doi.org/10.3390/jtaer16040057. 
Singh, N., \& Keating, B. M. (2018). Hyper-Localizing E-Commerce Strategy: An Emerging Market Perspective. In: Dwivedi, Y. et al. (eds). Emerging Markets from a Multidisciplinary Perspective. Advances in Theory and Practice of Emerging Markets, 89-94). Springer, Cham.

Sun, Y., Gonzalez-Jimenez, H., \& Wang, S. (2021). Examining the Relationship Between e-WOM, Consumer Ethnocentrism and Brand Equity. Journal of Business Research, 130, 564-573. https://doi.org/10.1016/j.jbusres.2019.09.040.

Tran, G. A., \& Strutton, D. (2020). Comparing Email and SNS Users: Investigating e-Servicescape, Customer Reviews, Trust, Loyalty, and e-WOM. Journal of Retailing and Consumer Services, 53, 101782. https://doi.org/10.1016/j.jretconser.2019.03.009.

Tribune. (2020). Covid-19 boosts digital economy, ecommerce in Pakistan. https://tribune. com.pk/story/2253806/covid-19-boosts-digital-economy-e-commerce-in-pakistan

United Nations Conference on Trade and Development. (2021). Global e-commerce jumps to $\$ 26.7$ trillion, COVID-19 boosts online sales. unctad.org/news/global-e-commercejumps-267-trillion-covid-19-boosts-online-sales

Verma, S., \& Yadav, N. (2021). Past, Present, and Future of Electronic Word of Mouth (EWOM). Journal of Interactive Marketing, 53, 111-128.

Wang, Y., Hong, A., Li, X., \& Gao, J. (2020). Marketing Innovations During a Global Crisis: A Study of China Firms' Response to COVID-19. Journal of Business Research, $116,214-220$.

Webster, F. E., \& Keller, K. L. (2004). A Roadmap for Branding in Industrial Markets. Brand Management, 1(5), 388-402.

Wenying, W., \& Quan, S. (2010). Analysis The Factors Affecting Consumers to Use Internet Banking Services. 2nd IEEE International Conference on Information Management and Engineering, 180-184.

Wu, S. I., \& Lo, C. L. (2009). The Influence of Core-Brand Attitude and Consumer Perception on Purchase Intention Towards Extended Product. Asia Pacific Journal of Marketing and Logistics, 21(1), 174-194.

Yoo, C. W., Sanders, G. L., \& Moon, J. (2013). Exploring The Effect of e-WOM Participation on e-Loyalty in e-Commerce. Decision Support System, 55(3), 669-678. https://doi.org/10.1016/j.dss.2013.02.001.

Yu, S., \& Lee, J. (2019). The Effects of Consumers' Perceived Values on Intention to Purchase Upcycled Products. Sustainability, 11(4), 1034.

Yu, T. K., \& Wu, G. S. (2007). Determinants of Internet Shopping Behavior: An Application of Reasoned Behaviour Theory. International Journal of Management, 24(4), 744-766.

Zeithaml, V. A., Parasuraman, A., \& Malhotra, A. (2002). Service Quality Delivery Through Websites: A Critical Review of Extant Knowledge. Journal of The Academy of Marketing Science, 30(4), 362-375. 
Zhou, S., McCormick, H., Blazquez, M., \& Barnes, L. (2019). eWOM: The Rise of The Opinion Leaders. In: Boardman, R., Blazquez, M., Henninger, C., Ryding, D (eds). Social Commerce, 189-212. Palgrave Macmillan, Cham.

Zhu, F., \& Zhang, X. (2010). Impact of Online Consumer Reviews on Sales: The Moderating Role of Product and Consumer Characteristics. Journal of Marketing, 74(2), 133-148. 